\title{
International Registration Data Identifier
}

National Cancer Institute

\section{Source}

National Cancer Institute. International Registration Data Identifier. NCI Thesaurus. Code C74929.

An internationally unique identifier for a data element. 